\title{
УДК 373.5.016:004
}

\author{
Овчарук Оксана Василівна \\ кандидат педагогічних наук, старший науковий співробітник, \\ завідувач відділу компаративістики інформаційно-освітніх інновацій \\ Інститут інформаційних технологій і засобів навчання НАПН України, м. Київ, Україна \\ oks.ovch@hotmail.com
}

Сороко Наталія Володимирівна

кандидат педагогічних наук, старший науковий співробітник

Інститут інформаційних технологій і засобів навчання НАПН України, м. Київ, Україна

nvsoroko@gmail.com

\section{ВИКОРИСТАННЯ ІНСТРУМЕНТІВ ОЦІНЮВАННЯ ІНФОРМАЦИИНО- КОМУНІКАЦЙНОЇ КОМПЕТЕНТНОСТІ ВЧИТЕЛІВ У КРАЇНАХ ЄВРОПИ}

\begin{abstract}
Анотація. У статті розглянуто питання використання інструментів оцінювання інформаційно-комунікаційної компетентності вчителів у країнах Свропи. Розглянуто рамку нової грамотності для характеристики майстерності особистості щодо володіння i застосування IКТ, що охоплює здатність людини застосовувати знання, уміння та навички 3 використання IКТ у професійній діяльності та повсякденному житті, і містить три основних блоки: технологічна досвідченість, грамотність, когнітивна досвідченість. Такими інструментами є тести, які мають охоплювати перевірку знань, умінь і навичок щодо використання IКТ для рішення технологічно-організаційних завдань й етичних ситуацій у навчально-виховному процесі ЗНЗ, самонавчанні та повсякденному житті. Виокремлюють он-лайн тестування, за допомогою такого програмного забезпечення, що дозволяє інтеграцію з освітніми порталами, сучасними браузерами та пристроями.
\end{abstract}

Ключові слова: оцінювання інформаційно-комунікаційної компетентності; інструментів оцінювання; інформаційно-комунікаційна компетентність вчителів.

\section{1. ВСТУП}

Швидкоплинність соціальних змін вимагає нових стратегії розвитку суспільства на основі знань і високоефективних технологій. Зростає значення освіти як головного чинника, що сприяє адаптації молоді в умовах інформаційного суспільства. Особлива роль наразі відводиться вчителеві, його професіоналізму, загальній культурі, володінню компетентностями 21 століття.

Постановка проблеми. Нині існує низка проблем, які пов'язані зі станом сформованості в учителів необхідних професійних компетентностей, серед яких ключову роль відіграє інформаційно-комунікаційна компетентність (IКкомпетентність). У зв’язку з цим актуальності набувають питання оцінювання ІКкомпетентності вчителів у контексті їхньої загальної професійної компетентності в умовах навчання впродовж життя. Аналіз динаміки розвитку ІК-компетентності вчителя, зокрема оцінювання, має відбуватись, враховуючи загальносвітові та європейські тенденції таких процедур і сприяти створенню відповідних умов i розробленню навчальних матеріалів для підвищення кваліфікації педагогів, їхньої адаптації до швидкого розвитку інформаційно-комунікаційних технологій (IКТ), нових вимог і викликів інформаційного суспільства. Адекватні інструменти оцінювання IКкомпетентності вчителя покликані забезпечити не тільки усвідомлення якості й підготовленості педагога до роботи з ІКТ, а й сприяти широкому використанню нових технологій для професійної діяльності і самовдосконалення.

Аналіз останніх досліджень i публікацій. Питанням оцінювання ІК- 
компетентності вчителів присвячені роботи вітчизняних дослідників В. Ю. Бикова, А. М. Гуржія, М. І. Жалдака, Н. В. Морзе, С. О. Семерікова, О. М. Спіріна та ін.

Основний акцент цих досліджень спрямований на виокремлення інструментів, процедур, принципів і критеріїв оцінювання ІК-компетентності суб'єктів навчальновиховного процесу загальноосвітнього навчального закладу (ЗНЗ). Врахування результатів, що представлені в роботах зазначених авторів, дозволяє впливати на зміст, форми, методи та засоби методичної підготовки учнів і різних категорій педагогічних працівників (учителів, методистів, керівників навчальних закладів), що надає можливості оптимізувати використання ресурсів навчального середовища для підвищення якості освіти й самореалізації педагогів і учнів.

У проведенні оцінювання ІК-компетентності вчителів особливого значення набуває досвід країн Європи. Так, дослідженню цих питань присвячені роботи зарубіжних науковців В. Даіете (Dagiene V. (Литва)), Е. Келвені (Calvani A. (Італія)), Е. Коітла (Koitla E. (Естонія)), Н. Крус (N. Kroes (Нідерланди)), М. Лаанпере (Laanpere M. (Естонія), М. Озолс (Ozols M. (Латвія)), М. Собі (Soby M. (Норвегія)), А. Феррарі (Ferrari A. (Бельгія)) та ін.

3 огляду на вище зазначене, метою статті $\epsilon$ характеристика ефективних інструментів оцінювання ІК-компетентності вчителів з досвіду країн Свропи.

\section{2. РЕЗУЛЬТАТИ ДОСЛІДЖЕННЯ}

Оцінювання рівня сформованості інформаційно-комунікаційної компетентності вчителя лежить у межах сегменту освіти дорослих i, зокрема, післядипломної педагогічної освіти. Питання володіння ІК-компетентністю педагогів знаходиться в центрі уваги низки міжнародних порівняльних досліджень, що спрямовані на визначення якості освіти.

Нині педагогічні кола різних країн послуговуються набором різноманітних понять, що пов’язані зі здатністю людини використовувати інформаційнокомунікаційні технології у навчанні, роботі та повсякденному житті, і які тісно пов'язані 3 інформаційно-комунікаційною компетентністю. Так, наприклад, торкаючись питань володіння ІК-компетентністю, європейськими міжнародними організаціями і дослідниками під час проведення порівняльних оглядів щодо якості освіти в різних країнах використовується поняття «нова грамотність». Зокрема, віцепрезидент Свропейської комісії Н. Крус (Neelie Kroes), використовує термін «нова грамотність» (англ. the new literacy) для опису майстерності особи в опануванні IКТ. На iii думку, «світ он-лайн $\epsilon$ великою частиною того, що ми робимо нині, адже компетентності й навички у сфері ІКТ стають головними на ринку праці» [1].

Дослідники Ш.-К. Венг (Shiang-Kwei Wang), К. Сомес (Thomas C. Reeves), які присвятили свої роботи вищеозначеному поняттю, надали своє бачення й опис рамки нової грамотності для характеристики майстерності особистості щодо володіння i застосування IКТ (рис. 1) [2].

Подана рамка охоплює здатність людини застосовувати знання, уміння та навички з використання IКТ у професійній діяльності й повсякденному житті. Рамка містить три основних блоки, які автори відносять до поняття «нова грамотність»: технологічна досвідченість, грамотність, когнітивна досвідченість. Наразі під досвідченістю автори розуміють не тільки знання, а й здатність людини застосовувати їх на практиці. Так, до технологічної досвідченості автори відносять знання, уміння та навички використовувати апаратне забезпечення, мережі та інші засоби IКТ. До грамотності віднесено здатність особи писати, читати, розуміти та спілкуватись. До когнітивної досвідченості автори віднесли критичне мислення й уміння розв'язувати проблеми. 


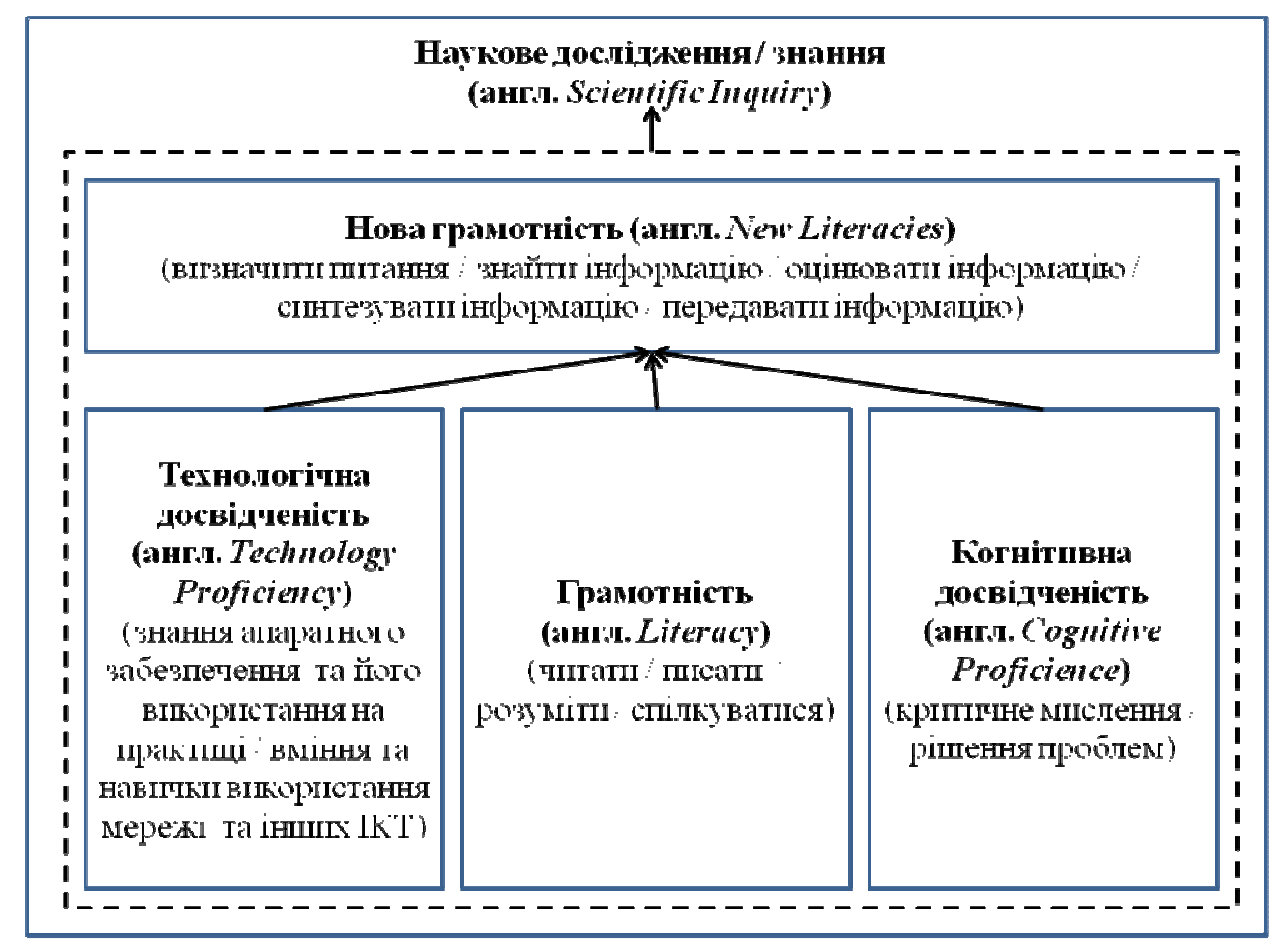

Рис. 1. Рамка нової грамотності для характеристики майстерності особи щодо володіння IKT [2]

Нині існує низка міжнародних програм, присвячених накопиченню даних щодо порівняння й оцінювання рівня ІК-компетентності учнів і дорослих користувачів у різних країнах. Зокрема, Програма міжнародної оцінки компетентностей дорослих (PIAAC-Programme for the International Assessment of Adult Competencies), є однією 3 програм Організації економічного співробітництва та розвитку (ОЕСР), що носить назву «Оцінювання рівня навичок он-лайн» (англ. Education and skills online assessment), яка присвячена проведенню досліджень щодо сформованості IКкомпетентності дорослих, зокрема, у порівнянні залежності рівня володіння нею до рівня заробітної плати [3].

Ця програма вимірює рівень низки когнітивних і не когнітивних навичок осіб, необхідних для участі у житті сучасного суспільства. Ці навички відносяться до сфери здатності і спроможності розуміти і використовувати друковані й електронні тексти, бути обізнаними в обчисленнях, уміти розв'язувати проблеми застосування інформаційно-комунікаційних технологій. Дослідники користуються такими трьома поняттями для вимірювання [3]: грамотність (англ. literacy), обчислювання (англ. numeracy), розв'язання проблем в IКТ-насиченому середовищі. При цьому IКТнасичене середовище [3] включає в себе мобільні робочі місця 3 постійним широкосмуговим доступом у мережу Інтернет в організації і вдома для кожного співробітника; єдине цифрове інформаційне середовище (сайт інституту, портал та ін.); систему постійного технічного обслуговування і технічної підтримки всіх користувачів.

Грамотність (застосовується для вимірювання рівня грамотності щодо того, як особа розуміє, використовує, інтерпретує, відображає та оцінює інформаційні матеріали з різних джерел (газет, брошур, посібників, Веб-сторінок та ін.). Водночас вимірюється рівень навичок читання текстів у трьох аспектах: словниковий запас, розуміння речення, розуміння всього тексту.

Оцінювання когнітивних навичок відбувається через вимірювання рівня 
грамотності й обчислювання, а також завдяки додатковим модулям з читання і розв'язання проблем у технологічно-насичених середовищах.

Обчислювання застосовується, щоб дізнатись, як особа виявляє здатність інтерпретувати, передавати та використовувати математичні дані для розв'язання проблем і розуміння ситуації. Дослідження використовує такий інструментарій, як таблиці, графіки, мапи, ярлики та рекламну інформацію. Завдання 3 обчислювання відповідають різним рівням складності й передбачають: сутність і ступінь інтерпретації й відображення задачі; репрезентативні, математичні навички, аргументацію, ступінь обізнаності 3 контекстом задачі, можливість й кроки щодо розв'язання задачі, застосовуючи новизну для її рішення та виявляючи креативний підхід.

Розв'язання проблем у ІКТ-насиченому середовищі організовано у трьох основних вимірах: когнітивні стратегії та процеси, що використовує людина для розв'язання проблеми, постановка проблеми, що призводить до старту розв'язання проблеми і вибору умов і технологій, які дозволяють іiі розв'язати. Ці три виміри полягають у:технологічних аспектах (передбачає типи додатків, кількостей та необхідних варіантів, використання засобів); аспектах задач (кількість необхідних кроків, кількість осіб, що повинні працювати над розв’язанням задачі); когнітивному процесі (за умови визначеної цілі, використання критеріїв, вимог для процесу моніторингу й оцінювання, рівень обгрунтування).

Слід зазначити, що дослідження передбачає поєднання різних варіацій і ступеню складності вирішення поставлених перед респондентом задач; використання різноманітних стратегій, серед яких - визначення цілей, можливість тупикових ситуацій; постановка задачі, що вимагає використання декількох технологічних середовищ (наприклад, респонденти мають використовувати відразу електронну пошту, та таблиці різної складності).

Питання 3 розв'язання проблем $\mathrm{y}$ технологічно насичених середовищах спрямовані на те, щоб виміряти, наскільки добре людина може використовувати різні технології для розв'язання щоденних проблем і складних задач й успішно досягати поставлених цілей. Також важливим у даних питаннях $є$ визначити, як особа розуміє $\mathrm{i}$ використовує відомості і дані у різноманітних середовищах, як, наприклад, електронне листування, Веб-сторінки, таблиці та ін. Оскільки переважно перевірка здатності вчителя розв'язувати вищезазначені проблеми відбувається переважно шляхом тестування, то такі типи тестів можуть містити завдання, під час виконання яких людина повинна використати стратегії, що раніше не застосовувала.

Важливо у впровадженні вимірювання рівня володіння ІК-компетентністю звернути увагу на визначення того, що саме слід розуміти під процесом оцінювання ІКкомпетентності і які існують інструменти оцінювання ІК-компетентності.

Виходячи 3 визначень авторів, що торкаються питань оцінювання навчальних досягнень (Вашуленко О. В., Жук Ю. О., Савченко О. Я. та ін.), а також авторів, які досліджують питання оцінювання ІК-компетентності суб' єктів навчального процесу (Биков В. Ю., Жалдак М. І., Ляшенко О. І., Морзе Н. В. та ін.), і погоджуючись з їхніми підходами, у контексті розвитку ІК-компетентності вчителів, ми розуміємо процес оцінювання як систему, що включає методи, засоби і технології отримання i використання результатів об'єктивних педагогічних вимірювань їх професійних досягнень, відповідно до критеріїв, що зазначаються у міжнародних стратегічних документах, які пропонуються у рамках визначення рівнів цієї компетентності [4]. Це оцінювання має охоплювати [5]:

- готовність учасників навчального процесу використовувати IКТ;

- здатність особистості застосовувати сучасні ІКТ для розв'язання навчальних i наукових проблем; 
- відповідні знання, навички та вміння застосовувати IКТ для професійної діяльності;

- ціннісні орієнтації вчителів і їхнє ставлення до використання IКТ в процесі навчання, роботи та дозвілля.

Виділяють [5-7] такі інструменти оцінювання IК-компетентності вчителів, як тести, анкети, електронне портфоліо, есе та ін.

Вчені країн СС [5-7], вважають, що найбільш вдалим інструментом оцінювання ІК-компетентності вчителів $є$ тест, оскільки надає можливість швидко провести процедуру оцінювання. Пропонують такі види тестів [6]: миттєвий (англ. instant), ситуативні (англ. situated), проективні (англ. projective).

Відповідно до Європейської рамки е-компетентності (European E-competence Framework) дослідники [6-8] пропонують створювати тестові завдання у трьох вимірах (рис. 2): технологічному, етичному та когнітивному. При цьому допускається їх інтеграція між собою. Нижче на рисунку 2 подано так звану рамку вимірів цифрової компетентності. При цьому, під технологічним виміром учені розуміють здатність гнучко використовувати та вирішувати проблеми й діяти у нових технологічно насичених середовищах; під когнітивним виміром - здатність читати, відбирати, інтерпретувати та оцінювати дані і відомості, враховуючи їхню доречність і надійність; під етичним - здатність конструктивно, відповідально та змістовно взаємодіяти 3 іншими, використовуючи відповідні технології. Інтеграція між трьома вимірами означає усвідомлення того потенціалу, що пропонується технологіями, які надають особі можливість поширювати інформацію і спільно будувати нові знання.

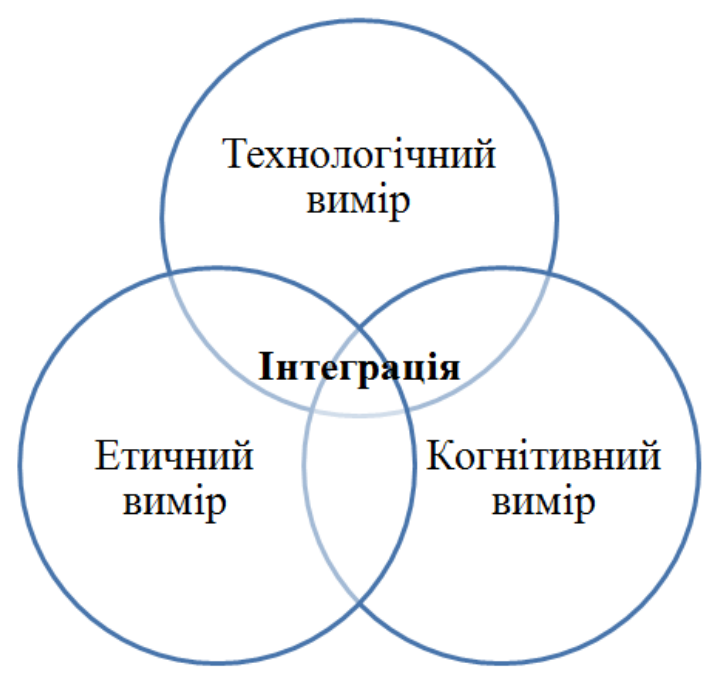

Рис. 2. Рамка циифрової компетентності особистості [8]

Розглянемо, як співвідносяться вищезазначені виміри (технологічний, етичний та когнітивний) (рис. 2) з видами тестів (миттєвим, ситуативним та проективним) [6].

Миттєві тести передбачають швидку відповідь на поставлене запитання і складаються, зазвичай, з питання і варіантів відповідей, серед яких слід обрати одну чи декілька правильних. Вони можуть бути спрямовані на технологічний, етичний або когнітивний контекст без їх інтеграції між собою.

На рисунку 3 схематично представлена карта миттєвого тесту як інструменту оцінювання ІК-компетентності вчителів [8], що покладена в основу побудови таких тестів (наприклад, тести European Computer Driving License (ECDL) побудовані саме за цією картою). 


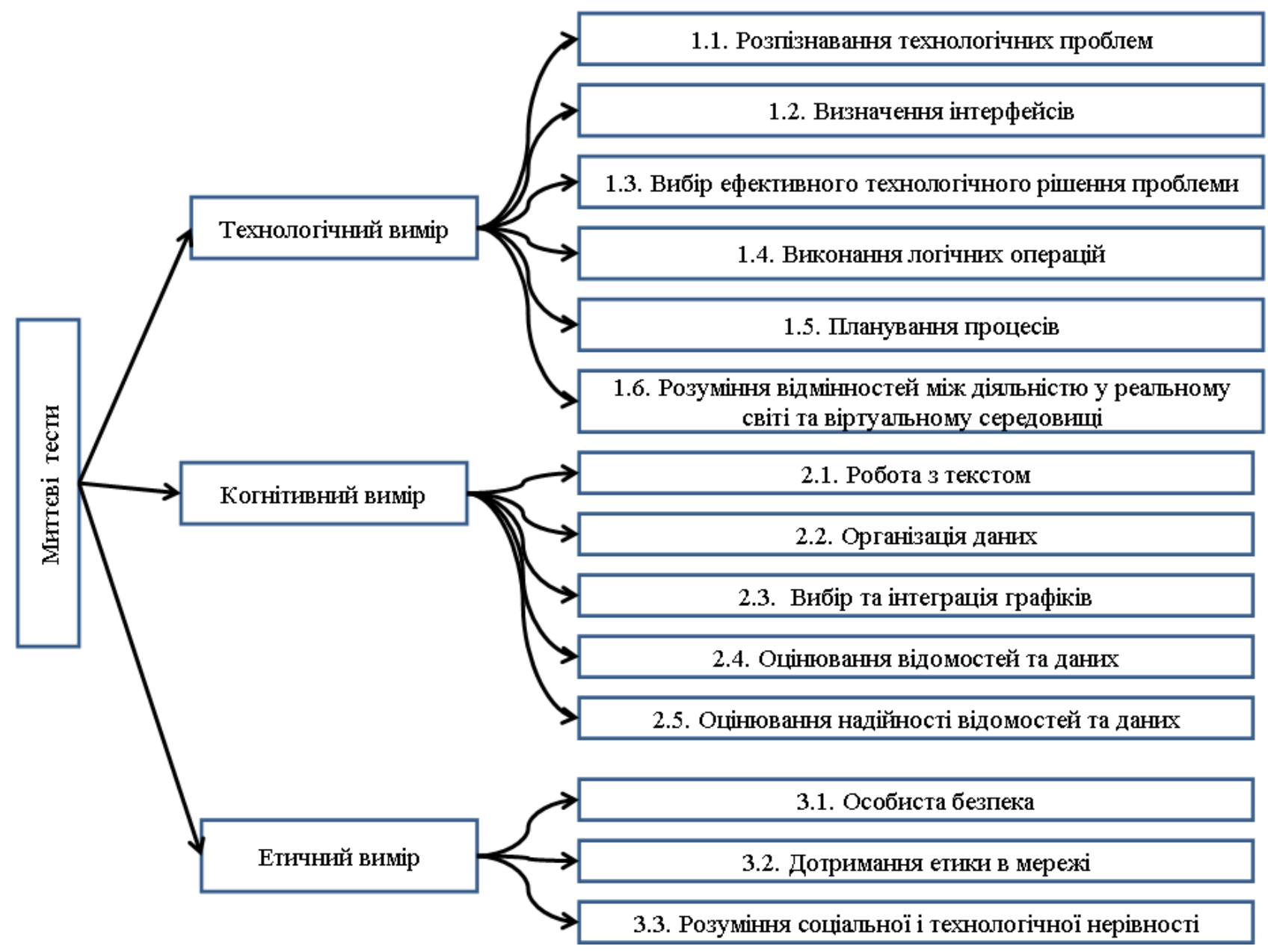

Рис. 3. Карта миттєвого тесту як інструменту оцінювання IК-компетентності вчителів [8]

Розглянемо більш докладніше кожен контекст у межах миттєвого тесту [8] щодо оцінювання ІК-компетентності вчителів.

Технологічний вимір охоплює подані нижче завдання.

1.1. Розпізнавання технологічних проблем (англ. Recognizing technological troubles) - вміння визначати найбільш поширені технічні ситуації, що вимагають здатності їх рішення з використанням IКТ (наприклад, у завданнях можуть бути наведені конкретні приклади і можливі сценарії/шляхи їх розв'язання, з яких той, хто проходить тест, повинен обрати найбільш раціональний).

1.2. Визначення інтерфейсів (англ. Identifying interfaces) - уміння адаптуватися до інтерфейсів, наприклад, використання панелі управління, будь-якого програмного забезпечення, сайту, Веб-сервісу та ін.

1.3. Вибір ефективного технологічного вирішення проблеми (англ. Selecting the most suitable technological solution) - уміння і здатності вибирати правильний інструмент для конкретного завдання.

1.4. Виконання логічних операцій (англ. Dealing with Logical Operations) уміння використовувати логічні оператори, які звичайно використовуються в програмуванні і пошуку даних.

1.5. Планування процесів (англ. Charting out processes) - уміння використовувати блок-схеми, програми, інструкції та інші сервіси для опису потоку даних. 
1.6. Розуміння відмінностей між діяльністю у реальному світі й віртуальному середовищі (англ. Distinguishing reality from the virtual world) - уміння і навички розпізнавати реальний і віртуальний світи.

Когнітивний вимір охоплює зазначені нижче завдання.

2.1. Робота 3 текстом (англ. Dealing with text (summarizing, representing, analyzing)) - знання текстових редакторів, уміння виокремлювати важливі відомості й дані для їх подальшого оцінювання і редагування.

2.2. Організація даних (англ. Organizing data) - знання програм для класифікації відомостей, уміння класифікувати дані (наприклад, за допомогою таблиць, 3 використанням різних ієрархічних структур та ін.).

2.3. Вибір способу графічного зображення і його інтерпретація (англ. Selecting and interpreting graphs) - знання графічних редакторів, уміння представляти інформацію в різних графічних формах, вибирати доцільні типи графіків відповідно до поставлених завдань, здатність аналізувати й інтерпретувати різні типи графіків;

2.4. Оцінювання даних (англ. Evaluating relevant information) - знання Веб-сервісів для пошуку відомостей.

2.5. Оцінювання надійності даних (англ. Evaluating information reliability) - уміння демонструвати свою здатність критично оцінювати надійність отриманих відомостей.

Етичний вимір охоплює завдання, що орієнтовані на поданому далі.

3.1. Особиста безпека (англ. Safeguarding oneself) - уміння керувати особистими даними, будучи інформованими про можливі ризики, що зустрічаються в Інтернеті.

3.2. Дотримання етики в мережі (англ. Respecting on the net) - знання мережного етикету, уміння поважати і визначати інтелектуальну власність і конфіденційність інших.

3.3. Розуміння соціальної і технологічної нерівності (англ. Understanding social and technological inequality) - розуміння поняття «цифрового розриву», усвідомлення соціальної і культурної нерівності у використанні технологій.

Учені приходять до висновку, що оцінювання ІК-компетентності вчителів відповідно до вище зазначених вимірів, можливо за допомогою миттєвих і ситуативних тестів [4-8].

Наразі ситуативні тести передбачають розв'язання проблеми за допомогою IКТ 3 урахуванням певних умов. Тестове завдання складається з описаної реальної ситуації (наприклад, створення аканту на порталі освіти) і запропонованих шляхів розв'язання проблем, які можуть виникнути у даній ситуації (наприклад, шляхи вирішення реєстрації на сайті, створення профілю на сайті, створення групи за інтересами у форумі та ін.) [4].

Такі тести можуть бути спрямовані на поєднання різних вимірів.

Ситуативні тести класифікуються за чотирма типами [6]:

- перший тип - «технологічна розвідка» (англ. Technological Exploration) пропонуються завдання, для виконання яких необхідно опанувати новою інформаційно-комунікаційною технологією;

- другий тип - «симуляція» (англ. Simulation) - у завданнях пропонуються дані, які мають бути емпірично опрацьовані й, відповідно до їх аналізу, може бути висунута гіпотеза щодо ефективного використання ІКТ для викладання певної навчальної дисципліни;

- третій тип - «розслідування» (англ. Inquiry) - у завданнях пропонується зібрати відомості й дані за певною темою, критично оцінити та відібрати їх для розв'язання поставленої проблеми;

- четвертий тип - «робота в групі» (англ. Collaborative) - завдання плануються для їх розв'язання у групі. 
Поряд із вище зазначеними видами тестів, для визначення рівня ІКкомпетентності вчителів пропонують [6] застосовувати так звані «проектні тести». Проективні тести полягають у проектуванні перспектив розвитку певної ситуації за допомогою використання IКТ (наприклад, спроектувати навчання учнів у полікультурному віртуальному середовищі).

Слід звернути увагу, що серед інструментів оцінювання ІК-компетентності вчителів особливо виокремлюють роль саме он-лайн тестування, оскільки воно забезпечує $[4 ; 6 ; 9]$ :

- адекватний аналіз загального стану ІК-компетентності вчителів;

- вільний доступ до матеріалів для здійснення сертифікації вчителів у галузі IКТ;

- швидку статистичну обробку результатів анкетування і тестування вчителів, як для надання їм сертифікатів щодо рівня IК-компетентності, так і для самооцінювання.

Створення i підбір програмного забезпечення для он-лайн тестування відбувається з урахуванням того, що такі інструменти зможуть забезпечити відкритий доступ користувачів до матеріалів, сумісність із національними освітніми порталами, сучасними браузерами, програмними продуктами провідних компаній, таких як Microsoft, IBM та ін. [6; 7].

Найвідомішими інструментами у країнах $\mathrm{CC} є$ «Міжнародні комп’ютерні права» (англ. International Computer Driving Licence) [4], «Європейські комп’ютерні права» (англ. European Computer Driving Licence) [4], «Шкільний наставник» (англ. School Mentor) та «Вчитель-наставник» (англ. Teacher Mentor) у Норвегії [9], Моя цифрова компетентність (англ. DigiMina (DigitalMe in Estonian)) в Естонії [4], мережа Комп'ютер у школі (Computing at School) та мережа Увімкнено Комп'ютинг (Switched on Computing) у Великої Британії [11] та ін.

Відповідно до досліджень вітчизняних науковців [4-10; 12; 13], серед засобів, які забезпечують он-лайн тестування, пропонують такі: платформи для підтримки дистанційного навчання (наприклад, Moodle, Pleiad, Promethee, WebCT, LearningSpace, Claroline, ACOLAD, Ganesha, VirtualU та ін. [12]), Веб-сервіси для створення он-лайн тестів (наприклад, Google Drive, Quizlet, Proprofs, ClassMarker та ін. [4 10]), веб-сервіси для створення он-лайн анкетування (наприклад, Examinare, Survey Monkey, The Survey System та ін. [13]) тощо.

Слід зазначити, що всі подані вище інструменти оцінювання ІК-компетентності вчителів, що пропонують зарубіжні педагогічні кола, спрямовані на забезпечення адекватного аналізу реального стану здатності вчителя ефективно застосовувати знання, уміння та навички у галузі ІКТ у своїй професійній діяльності, а також вони можуть бути використані для проектування спеціалізованих курсів у сфері підвищення кваліфікації вчителів.

\section{3. ВИСНОВКИ ТА ПЕРСПЕКТИВИ ПОДАЛЬШИХ ДОСЛІДЖЕНЬ}

Проведений аналіз досліджень науковців країн Європи з питань оцінювання ІКкомпетентності вчителів дає можливість зробити певні висновки.

Під час оцінювання рівня ІК-компетентності вчителя варто враховувати рамку нової грамотності для характеристики майстерності особистості щодо володіння i застосування IКТ, що охоплює здатність людини застосовувати знання, уміння та навички 3 використання IКТ у професійній діяльності й повсякденному житті, та містить три основних блоки: технологічна досвідченість, грамотність, когнітивна досвідченість.

Вдало підібраний інструмент оцінювання ІК-компетентності вчителів забезпечить адекватний аналіз реального стану знань, умінь і навичок учителів доцільно й 
ефективно використовувати ІКТ у професійній діяльності і допоможе у проектуванні спеціалізованих курсів підвищення кваліфікації вчителів у цій галузі.

Найефективнішими інструментами для оцінювання ІК-компетентності вчителів визначають тести, зокрема, он-лайн тести, що мають охоплювати перевірку здатності вчителя ефективно і відповідально застосовувати знання, уміння та навички у використанні IКТ для рішення технологічно-організаційних завдань й етичних ситуацій у навчально-виховному процесі ЗНЗ, для самовдосконалення й у повсякденному житті.

Оскільки процес оцінювання повинен бути мобільним, швидким, зручним та гнучким, особливої уваги приділяють створенню он-лайн тестів за допомогою такого програмного забезпечення, що дозволяє інтеграцію з освітніми порталами, сучасними браузерами і пристроями.

Перспективами подальших досліджень слід визначити, перш за все, аналіз вітчизняних розробок $з$ питань оцінювання ІК-компететності вчителів, зокрема, створення та застосування он-лайн тестів для оцінювання ІК-компетентності вчителів й адаптацію позитивного досвіду зарубіжних країн з цієї проблеми.

\section{СПИСОК ВИКОРИСТАНИХ ДЖЕРЕЛ}

1. Овчарук О. В. Проблеми оцінювання інформаційно-комунікаційної компетентності в системі загальної середньої освіти: загальні підходи [Електронний ресурс] / О. В.Овчарук // Інформаційні технології і засоби навчання. - 2014. - № 6 (44). - Режим доступу : http:// journal.iitta.gov.ua/index.php/itlt/article/download/1162/880.

2. Neelie Kroes. Two Europes or One Europe? [online]. - Available from : http://europa.eu/rapid/pressrelease_SPEECH-14-710_en.htm.

3. Shiang-Kwei Wang, Hui-Yin Hsu, Thomas C. Reeves, Daniel C. Coster. Professional development to enhance teachers' practices in using information and communication technologies (ICTs) as cognitive tools: Lessons learned from a design-based research study// Computers \& Education - 79. - 2014. - 101115 pp. [online]. -Available from : www.elsevier.com/locate/compedu.

4. Education and skills online assessment. The Online Version of PIAAC. A joint Initiative of the OECD and the European Union [online]. -Available from : http://www.oecd.org/skills/ESonline-assessment.

5. Сороко Н. В. Проблема оцінювання інформаційно-комунікаційної компетентності вчителів (досвід Литви та Естонії) / Н. В. Сороко // Компетентнісний підхід в освіті: теоретичні засади і практика реалізації: матеріали методол. семінару 3 квіт. 2014 р., м. Київ: [у 2 ч.]. Ч. 2 / Нац. акад. пед. наук України; [редкол.: В. Г. Кремень (голова), В. І. Луговий (заст. голови), О .І. Ляшенко (заст. голови) та ін.] - К.: Ін-т обдарованої дитини НАПН України, 2014 - 292 с., с. 239-248.

6. Calvani A., Fini A., Ranieri M. Assessing Digital Competence in Secondary Education - Issues, Models and Instruments/ A. Calvani, A. Fini, M. Ranieri //Issues in Information and Media Literacy: Education, Practice, and Pedagogy - Informing Science Press. - 2009 - P. 153-172

7. Ferrari A. Digital Competence in Practice: An Analysis of Frameworks / A. Ferrari // Luxembourg: Publications Office of the European Union. - 2012. - 95 p.

8. Benchmarking Digital Europe 2011-2015, a conceptual framework. i2010 High Level Group. ISSUENO: 27, October, 2009. European Commission [online]. - Available from : http://www.epractice.eu/files/Benchmarking\%20Digital\%20Europe\%202011-2015\%20$\% 20 \mathrm{~A} \% 20$ conceptual\%20framework.pdf.

9. Іванюк I. В. Використання он-лайн інструментів для оцінювання цифрової компетентності вчителів і керівників навчальних закладів у Норвегії/ І.В.Іванюк // Інформаційні технології і засоби навчання. - 2015 . $\quad$ - № 3 (47). - Режим доступу : http://journal.iitta.gov.ua/index.php/itlt/article/view/1237/925.

10. Cartelli A. Current Trends and Future Practices for Digital Literacy and Competence / A.Cartelli // IGI Global. - 2012. - 280 p.

11. Малицька І.Д. Оцінювання ІК-компетентності учнів у школах Великої Британії [Електронний ресурс] / І.Д.Малицька // Інформаційні технології і засоби навчання. - 2015. - № 5 (49). - Режим доступу : http://journal.iitta.gov.ua/index.php/itlt/article/view/1297/962

12. Oubahssi L. Conception de plates-formes logicielles pour la formation à distance, présentant des propriétés d'adaptabilité à différentes catégories d'usagers et d'interopérabilité avec d'autres environnements logiciels: Thèse de doctorat...spécialité informatique. Université René Descartes Paris V. 
$-2005 .-301 \mathrm{p}$.

13. Gube J. 7 Best Practices for Improving Your Website's Usability / Jacob Gube // Mashable. - 2011. [online]. -Available from : http://mashable.com/2011/09/12/website-usability-tips.

Матеріал надійшов до редакиї 12.04.2016 p.

\title{
ИСПОЛЬЗОВАНИЕ ИНСТРУМЕНТОВ ОЦЕНИВАНИЯ ИНФОРМАЦИОННО- КОММУНИКАЦИОННОЙ КОМПЕТЕНТНОСТИ УЧИТЕЛЕЙ В СТРАНАХ ЕВРОПЫ
}

\author{
Овчарук Оксана Васильевна \\ кандидат педагогических наук, старший научный сотрудник, \\ заведующая отделом компаративистики информационно-образовательных инноваций \\ Институт информационных технологий и средств обучения НАПН Украины, г. Киев, Украина \\ oks.ovch@hotmail.com
}

\section{Сороко Наталия Владимировна}

кандидат педагогических наук, старший научный сотрудник

Институт информационных технологий и средств обучения НАПН Украины, г. Киев, Украина nvsoroko@gmail.com

\begin{abstract}
Аннотация. В статье рассмотрены вопросы использования инструментов оценивания информационно-коммуникационной компетентности учителей в странах Европы. На основе анализа опыта европейских стран выделены и охарактеризованы наиболее эффективные инструменты оценки информационно-коммуникационной компетентности учителей. Такими инструментами являются тесты, которые должны охватывать проверку знаний, умений и навыков использования ИКТ для решения технологически-организационных задач и этических ситуаций в учебно-воспитательном процессе средней школы, самообучении и повседневной жизни. Выделяют он-лайн тестирование, с помощью такого программного обеспечения, которое позволяет интеграцию с образовательными порталами, современными браузерами и устройствами.
\end{abstract}

Ключевые слова: оценивание информационно-коммуникационной компетентности; инструменты оценивания; информационно-коммуникационная компетентность учителя.

\section{USING OF THE TEACHERS' INFORMATION AND COMMUNICATION COMPETENCY ASSESSMENT INSTRUMENTS IN EUROPEAN COUNTRIES}

\author{
Oksana V. Ovcharuk \\ $\mathrm{PhD}$ (pedagogical sciences), Senior Researcher, \\ Head of Comparative Studies Department for Information and Education Innovations \\ Institute of Information Technologies and Learning Tools of NAES of Ukraine, Kyiv, Ukraine \\ oks.ovch@hotmail.com

\section{Nataliia V. Soroko} \\ $\mathrm{PhD}$ (pedagogical sciences) \\ Institute of Information Technologies and Learning Tools of NAES of Ukraine, Kyiv, Ukraine \\ nvsoroko@gmail.com
}

\begin{abstract}
The article deals with the using of teachers' information and communication competency assessment instruments in European countries. It was considered the new literacy skills of the individual characteristics of possession and use of ICT, which covers the person's ability to apply knowledge and skills of ICT using in professional activities and daily lives. It comprises three main blocks: technological sophistication, literacy, cognitive experience. Such instruments are the tests, which should cover the verification of knowledge and skills to use ICT for solving technological, organizational problems and ethical situations in the educational process of secondary school, self-learning and everyday life. The online tests are allocated to use the adequate software, which allows integration with educational portals, modern browsers and devices.
\end{abstract}


Keywords: assessment of information and communication competency; assessment instruments; information and communication competence of teachers.

\section{REFERENCES (TRANSLATED AND TRANSLITERATED)}

1. Ovcharuk O. V. The problems of evaluation of information and communication competence in the system of general secondary education [online] / Ovcharuk O. V. // Information Technologies and Learning Tools. -2014.- $\quad \mathrm{N} \quad 6 \quad$ (44). $\quad$ - $\quad$ Available from : journal.iitta.gov.ua/index.php/itlt/article/download/1162/880 (in Ukrainian).

2. Neelie Kroes. Two Europes or One Europe? [online]. - Available from : http://europa.eu/rapid/pressrelease_SPEECH-14-710_en.htm (in English).

3. Shiang-Kwei Wang, Hui-Yin Hsu, Thomas C. Reeves. Daniel C. Coster Professional development to enhance teachers' practices in using information and communication technologies (ICTs) as cognitive tools: Lessons learned from a design-based research study// Computers \& Education - 79. -2014. - 101115 pp. [online]. - Available from : www.elsevier.com/locate/compedu (in English).

4. Education and skills online assessment. The Online Version of PIAAC. A joint Initiative of the OECD and the European Union [online]. - Available from : http://www.oecd.org/skills/ESonline-assessment (in English).

5. Soroko N. V. The problem of assessment teachers' information and communication competence (the experience of Lithuania and Estonia) / N.V. Soroko // Competence approach in education: theoretical principles and practice of implementation: methodological seminar materials. April 3, 2014, Kyiv [2 parts]. Part 2 / National Academy of Educational Sciences of Ukraine; [Editorial board: V.G. Kremin (chairman), V.I. Lugovoy (deputy chairman), O. Lyashenko (deputy chairman) and others.] - K .: Institute of the Gifted Child NAES Ukraine, 2014 - 292 pp., p. 239-248 (in Ukrainian).

6. Calvani A., Fini A., Ranieri M. Assessing Digital Competence in Secondary Education - Issues, Models and Instruments/ A.Calvani, A.Fini, M.Ranieri //Issues in Information and Media Literacy: Education, Practice, and Pedagogy -Informing Science Press. - 2009 - p. 153 - 172 (in English).

7. Ferrari A. Digital Competence in Practice: An Analysis of Frameworks / A.Ferrari // Luxembourg: Publications Office of the European Union. -2012 - 95 p. (in English).

8. Benchmarking Digital Europe 2011-2015, a conceptual framework. i2010 High Level Group. ISSUENO: 27, October, 2009. European Commission [online]. - Available from: http://www.epractice.eu/files/Benchmarking\%20Digital\%20Europe\%202011-2015\%20$\% 20 \mathrm{~A} \% 20$ conceptual\%20framework.pdf (in English).

9. Ivaniuk I.V. Using online tools for evaluation the digital competence of teachers and principals in norway [online] / I.V. Ivaniuk // Information Technologies and Learning Tools. - 2015. - N 3 (47). - Available from : http://journal.iitta.gov.ua/index.php/itlt/article/view/1237/925 (in Ukrainian).

10. Cartelli A. Current Trends and Future Practices for Digital Literacy and Competence / A.Cartelli // IGI Global. - 2012. - 280 p. (in English).

11. Malytska I. D. Assessment of pupils' IT-competency in Great Britain schools [online] / I.D.Malytska // Information Technologies and Learning Tools. - 2015. - № 5 (49). - Available from : http://journal.iitta.gov.ua/index.php/itlt/article/view/1297/962 (in Ukrainian).

12. Oubahssi L. Conception de plates-formes logicielles pour la formation à distance, présentant des propriétés d'adaptabilité à différentes catégories d'usagers et d'interopérabilité avec d'autres environnements logiciels: Thèse de doctorat...spécialité informatique. Université René Descartes Paris V. - 2005. -301 p. (in French).

13. Gube J. 7 Best Practices for Improving Your Website's Usability [online] / Jacob Gube // Mashable. 2011. - Available from : http://mashable.com/2011/09/12/website-usability-tips (in English).

Conflict of interest. The author has declared no conflict of interest.

\section{(c) $\mathrm{EY}$-NC-SA}

This work is licensed under Creative Commons Attribution-NonCommercial-ShareAlike 4.0 International License. 